\title{
The Need for Airport Funding
}

\author{
Robert W. Kaps, David A. New Myer, Richard T. Lanman and Jason Sigler \\ Southern Illinois University Carbondale
}

\begin{abstract}
As a major component of the aviation industry, airports today rely on huge amounts of capital to keep the avenues of air transportation open. The Airport and Airways Development Act of 1970 became effective in May 1970 and provided a major source of airport capital improvement funding. However, since this law was passed airport capital needs have grown well beyond the capabilities of the federal government to fund them. Airports face a different financial market than their industry contemporaries; due in part to the regulated public environment, the uniqueness of airport revenue generation and debt markets. The need for airport funding will be explained by exploring the basics of airport operating costs, capital costs and revenue generation. An investigation of capital finance strategies will bring the conclusion.
\end{abstract}

\section{BACKGROUND ON THE NEED FOR AIRPORT FUNDING}

Revenue generation in the airport business is derived from a broad base. Depending upon the size of an individual airport's operation, key users, and the infrastructure supporting that airport, major revenue sources may vary considerably. Besides deriving a portion of their revenue stream from airlines and other aviation users, airports collect revenues from a large contingency of non-aviation related concessions. These income sources flow from charges to businesses that use the airport for their own economic purposes and revenue streams. Some of these include rents for parking areas, restaurants, gift shops, rental car agencies, hotels, and industrial parks located on airport grounds. In some cases, airports collect a portion of a business' gross revenue as compensation, over and above standard rates (Wells, p 213).

The U.S. airport system is a unique breed of a capitalist structure. The Deregulation Act of 1978 removed barriers of entry and exit for airlines, permitting airlines to refine and change existing prederegulation route structures. Ease of entry and exit left some airports bewildered as former lifetime tenants vacated the premises. While deregulation changed the airlines' operating environment, a concomitant change occurred in the airport environment (Kaps, 235). A new era of revenue generation and bottom line results was ushered in and thrust upon the airport manager.

As with most businesses, an airport must rely on its ability to attract capital to remain viable. An airport's ability to obtain capital, other than through revenue generation, comes from either the debt or quasi-equity markets, with one major exception. Equity markets do not exist "per se" in airport terminology. This is so because, until recently, private capital had not been infused into the system. The funding of airports has been, and basically remains, a public general fund consideration. If an analogy can be drawn between stockholders of a corporation and citizens of a locale where an airport is located, airport stockholders are the citizens 
of the community or communities served by the airport. Rather than receive dividends in the form of money for their equity holdings, airport viability and community embellishment are the citizen's investment returns (Kaps, p. 234). As the vast majority of airports in America are publicly owned (municipalities, government, etc.) private investment has not been a consideration. Instead, federal, state and/or municipal moneys work as a traditional equity infusion of non-private industry. Should there be a return on this investment, it does not become the province of the stockholders, but rather, an increase to the general fund, which is ultimately, a benefit to the citizenry.

Air travel has been and remains one of the fastest growing global industries. Forecasts predict U.S. commercial aviation will see robust growth in the coming decades, with international air travel to and from the U.S. growing by almost $1 \frac{1}{2}$ times the rate of domestic traffic (U.S. DOT). Airport planners around the world have found it virtually impossible to keep pace with the growing number of passengers and the demand for additional facilities. Airport capacity problems arise in virtually every developed country in the world. In the United States, according to Whitlock (1992), the system has surpassed capacity in many areas and projections are that patronage will grow even faster in the next decade. In 1995, in a speech before the Aviation Management Society of Southern Illinois University Carbondale, the Administrator of the Federal Aviation Administration (FAA) predicted air travel in the U.S. would increase by $60 \%$ in the next ten years (Hinson). Airports around the world will be faced with accommodating as many as 1 billion passengers annually by the year 2008 (U.S. DOT). This projection requires new and existing airport capacity and the concomitant ability to fund this growth.
The need for airport funding in the United States is driven by the users of the system; the scheduled airlines, general aviation, and military. The National Plan of Integrated Airport Systems (NPIAS) 19901999 (February 1991) estimated the total cost of Federal, State, Local, and Private airport development to be $\$ 40.544$ billion. This estimate, prepared by the Federal Aviation Administration, includes the total cost of all projects eligible for federal support under the Airport Improvement Program, or AIP. This estimate included $\$ 6.153$ billion for new airports, including $\$ 4.742$ billion for new primary airports such as the Denver International Airport opened in February 1995. The FAA estimate for the DIA project was $\$ 2.4$ billion. Since DIA's total cost has come in at over $\$ 4.0$ billion, there's a serious estimate shortfall. Other costs estimated for the other primary airports in the NPIAS (Austin, TX; Chicago, IL; Lake Havasu, AZ; San Diego, CA, etc.) were for nominal planning and land acquisition costs. They did not include development costs. It should be noted that the new primary airport construction estimates amount to less than a fourth of the total costs estimated for the NPIAS from 1990 to 1999. The National Plan of Integrated Airport Systems 1998- 2002 (March 1999) estimates the total cost of Federal, State, Local, and Private airport development to be $\$ 35.093$ billion. The $\$ 5.451$ billion dollar cost reduction from the 1990-1999 NPIAS report is due to the fact that no new hub airports are currently being built in the U.S.

Another aspect of domestic need for airport finance is the huge costs involved in reconstructing or expanding the existing airport system. For example, several airports around the nation are actively planning to add additional runways to their current layouts as a way to add more airport capacity without building all-new airport 
sites (GAO/RCED 98-129). Examples of such airports are Dallas-Ft. Worth International (DFW), and St. Louis Lambert International (STL). STL is in the process of planning to add a third east-west runway, for which preliminary Federal Aviation Administration approval was granted in December 1997. When these plans are finalized, the need for additional airport funding will be acute because these airports are all planning multi-billion dollar projects.

In the United States, rules, regulation, politics, and public outcry can inhibit funding abilities and goal accomplishments. Justifying the expenditure of amounts of money greater than some countries entire Gross National Product, can prove exceedingly difficult. A definitive need, as well as a plan that ensures financial integrity, is necessary before the public, as well as private entities, will consider backing airport requirements.

\section{Internal Airport Funding Sources}

The ability of an airport to finance itself, both operationally and for capital projects, has a lot to do with whether it is served by an airline. Airlines, and their passengers, provide a regular, daily flow of revenue to the airport based on the scheduled service that is provided by the airlines. Airlines lease facilities, rent space, pay for fuel, etc. Passengers rent cars, pay car parking fees, purchase items from concessionaires, etc. All of this airlinerelated activity generates revenue for the airport operator (Jenkins).

The activity at a general aviation airport is unscheduled, which causes the flow of revenue to be relatively unpredictable. There are some critical, and highly utilized, general aviation airports, particularly in major metropolitan areas. However, without airline service, general aviation airports are missing a key ingredient for airport funding -a consistent source of daily revenue. In addition, general aviation airports are ineligible for the Passenger Facility Charge (PFC) revenue, which is also derived from airline passenger volume (FAR 158). Consequently, airport finance options for general aviation airports are somewhat more limited than their commercial service counterparts. Many very small general-aviation airports are almost totally dependent upon Airport Improvement Program (AIP) funding for capital development, due to their lack of local funding options.

\section{Cash Flow Considerations}

Before an airport operating body can consider expansion or replacement plans, it must first consider how the costs of its daily operations are paid. Key operating cost categories are:

1. Salaries of airport employees, including management/ administration, operations, maintenance, and, where applicable, security, police, airport rescue/fire fighting, etc.

2. Airport Utilities, including the operation of any on-airport plants, sub stations, etc.

3. Equipment costs, including mowers, snow removal vehicles, airfield maintenance/operations vehicles and, where applicable, airport police cars, airport security vehicles and airport rescue/fire fighting trucks

4. Materials costs, including paint, building material items, snow removal salt, fuel spill clean up agents, lighting items, etc.; and,

5. Other costs that pertain to specific airports, such as airport owned and operated air traffic 
control towers or aircraft fueling facilities.

In order to finance these operating costs, airports must consider a wide range of revenue generation possibilities for their airport, including:

1. Airfield or airside user charges. These are charges related to the use of runways, taxiways, ramps, hangars, and any other airport facilities on the operational side of the airport. Examples of such charges are aircraft landing fees (by weight, by aircraft type, by common fee for all, etc), aviation gas/jet fuel charges or fuel flowage fees, hangar rentals, aircraft parking/storage fees, etc.

2. Concessionaire fees. These are landside lease or rental charges which companies wishing to operate at the airport must pay to use the terminal, the fixed base operator building or any other on-airport building. Companies providing services such as airlines, air taxi/charter operators, flight schools, aircraft fueling, car rental, food service, business services, banking services, gift shopping, newspapers, can all expect to pay such charges. Charges can be assessed in terms of space used on the airport or in terms of units of business or sales volume or some combination thereof.

3. Local tax revenues. These can be general-purpose municipal taxes allocated to the airport by a city or county council. They can also be taxes assessed directly for the airport by an airport authority or district based on the assessed valuation in the area covered by the taxing units' voter-approved boundaries.
4. Agricultural fees. These are fees collected from farming and harvesting crops on airport owned lands by farmers. This is a special form of concession or lease fee.

5. Industrial Park Fees. Many airports have encouraged the development of non-aeronautical airport land use in such uses as industrial parks as a way to add revenue streams as well as a way to provide compatible land uses near runways. This is also a special form of concession or lease fees.

6. Mineral or mining fees. These are fees collected by the airport for oil, gas, or minerals pumped or mined from beneath the airport. This can be an important source of income in certain parts of the nation. (Kaps)

At air carrier served airports, the major tenants are the scheduled airlines. By means of rates and charges, these tenants are key to funding the operating and capital needs of airline served airports.

A major consideration to be made by airport personnel at airline-served airports in forecasting their projected revenues is how to suitably charge the airlines. Because such charges impact heavily on the airport's revenue stream, it is important to be both fair to the airline as well as to gain sufficient revenue to both operate the airport and have the ability to make interrelated major purchases.

\section{Setting Rates and Charges}

There are two major techniques used by airports to set airline rates and charges. These are the compensatory and the residual methods of ratemaking. Each method has a variety of subdivisions and approaches to their usage. The most prominent are the standard/commercial compensatory plans, 
the cost-center residual plan, and airportairline system residual methods. Each of these has their own advantages and disadvantages as the following discussion shows.

\section{Standard Compensatory}

This approach to rate-making considers airlines as the ultimate user of the terminal and all other facilities of the airport. Rates and charges are calculated so the airport fully covers the airlines' share of operation and capital costs of the entire facility. These costs are only those necessary to operate the airport as a landing and take off location. Costs incurred by the airport for the maintenance of public areas and concessionaires, such as parking areas, etc., are excluded from charges to the airline. In this case, should Air Atlantis fly into XYZ airport and be the only carrier operating out of that airport, the entire costs of the airport and its operation, exclusive of non-airline necessary operations, would be borne by Air Atlantis. The airport, under this arrangement, must ensure that the profits made from its non-airline operations exceed the non-airline costs. Otherwise, a profit situation will not inure to the airport.

\section{Commercial Compensatory}

Under this method of ratemaking, all costs are calculated by charging the airlines, the concessionaires, and all rent paying tenants pro-rata for concession space and public-area costs. Airline costs excluding those for maintenance of public and concession areas in the standard compensatory, are included under this method. Under both the standard and the commercial compensatory methods, the airport assumes the risk associated with vacant rental space, but can, and often times does, receive a portion of the concessionaires' gross revenues.

\section{Cost Center Residual}

The Cost Center Residual approach to rate setting establishes a cost center mentality. It allocates the cost of operating an airport to a particular area, as opposed to an all-encompassing approach of the entire operation. In other words, accounts are established for operational areas such as terminal, ground transportation, airfield, parking, staging areas, and other buildings and grounds operations. Rates and charges, particularly airlines' charges are set to recover the costs of this cost center. Charges are based on the usage of this area and any offset or credit that may be received due to non-airline revenue generated by the area. The net costs are then pro-rated to the airline or airlines involved.

\section{Airport/Airline System Residual}

This is an all-encompassing assumption of airport financial risk by the airlines. Under this arrangement, the airlines pay landing fees large enough to ensure that the airport breaks even. Under residual methods, the airlines primarily assume financial risk of airport operations. Because long-term leases may run twenty or thirty years, an airline may subject itself to pay costs of undefined future facilities. Generally, as quid pro quo for their financial solvency, an airline obtains lease arrangements satisfactory to their market share. Oftentimes, these arrangements create majority-in-interest clauses in their lease agreements, whereby airlines obtain sufficient influence to gain control over airport financial and investment decisions. Majority in interest arrangements may go so far as to permit the airline(s) to review, approve, and/or veto airport capital projects. 
Much consternation exists over the establishment of airport fees. In recent court cases, an airport's right to set rates and charges through a compensatory method has been affirmed. In 1995, Congress established new rate, fee, and charge guidelines. Code of Federal Regulation Title 14 Part 302 highlights that:

- rates established must be "fair and reasonable"

- rates may not unjustly discriminate against aeronautical users or other groups

- rates must be set so that the airport is financially selfsustaining as possible, and

- airport revenues must be expended for aeronautical facilities within that airport.

Once the method of cost allocation is determined, the airport director must determine the difference from anticipated revenues and the cost of operation. Under traditional accounting methods, revenue minus expense equals profit or loss. However, under the airport equation, revenue minus expense equals either costs covered, or an inability to cover costs. If costs are covered, revisions to scheduling or scope of proposed master projects might have to be made to keep the tight balance of costs to expenditures. In the alternative, where revenues do not cover airport costs, a short fall exists. When a short fall is either experienced or anticipated, a break-even need is created. This need creates the necessity for airports to seek other arrangements to secure required capital.

\section{Federal Airport Funding Sources}

Obtaining funds over and above the traditional revenue sources to support an airport's capital improvement needs generally falls into two categories: grants or debt. Grants are the receipt of money conferred by a fund for the purpose known to the conferring fund. The exceptional benefit of having a grant conferred is that fulfillment of the duty associated with such grant acts as payment of the principal amount conferred. In other words, free money. The debt market, on the other hand, confers money to the borrower but expects to have the principal returned, with a return of interest. Before going to the debt markets for additional funding, all avenues of "free" money should be exhausted. The avenue of approach should then be grants, other possibilities, and then the debt markets. According to Federal Aviation Regulation Part 151, airports have one additional predebt option after the grant route has been exhausted. The Passenger Facility Charge (PFC), which is regulated under Federal Aviation Regulation Part 158, may provide additional sources of revenue. Each of these areas will be briefly discussed.

Because the national infrastructure is dedicated to the support of the transportation system, particularly the air transportation system, the federal government has historically been the provider of airport developmental funds. This funding is provided primarily through the Airport Improvement Program (AIP). The Airport and Airway Improvement Act of 1982 established the AIP.

\section{The Airport and Airway Trust Fund}

The Airport and Airway Trust Fund supports the nation's aviation infrastructure, begun as part of the Airport and Airway Development Act of 1970. Zorn (1990) indicates the purpose of the fund was to support capital development of the nations' air transportation system and support part of the Federal Aviation Administration's operating and maintenance costs. 
The Trust Fund relies on user fees and taxes assessed on those who use the air system for development of its funding mechanism. Fund revenues are derived from:

- Taxes levied on all domestic airline tickets $(8 \%$, to drop to $7.5 \%$ in FY 2000)

- Ticket tax at rural airports (7.5\%)

- Flight segment tax $(\$ 2.25$, to raise to $\$ 3.00$ in FY 2003)

- Tax on "frequent flyer" awards $(7.5 \%)$

- Taxes levied on all freight airway bills $(6.25 \%)$

- International departure taxes assessed per passenger $(\$ 12.00)$

- International arrival taxes assessed per passenger $(\$ 12.00)$

- General Aviation gasoline taxes (19.3 cents per gallon)

- General Aviation jet fuel (21.8 cents per gallon)

- Commercial and jet fuel tax (4.3 cents per gallon)

Source: Budget of the United States Government FY 2000 Congressional Research Service

The principal advantage of the user approach to generating the trust funds is that it provides predictable and increasing sources of income, commensurate with need. This permits more effective and long range planning. It has been estimated that in fiscal year 1996, airline ticket purchases alone contributed in excess of $\$ 5.0$ billion to the fund. Despite this staggering amount, more could probably have been collected had it not been for the government shutdown during the Democratic and Republican debates over balancing the federal budget. Because of an oversight the Trust Fund fees were not extended into early fiscal 1997 and were not collected by the airline community. This provided windfall fares for the traveling public and a competitive edge for some airlines, but it did little for the fund itself. Early 1997 provided Congress the opportunity to reestablish the user charge and trust fund approach, which it did (U.S. House).

\section{The Airport Improvement Program (AIP)}

The Airport and Airway Improvement Act of 1982 established the Airport Improvement Program. Its funds, derived from the Airport and Airway Trust Fund, are used for four general purposes; airport planning, airport development, airport capacity enhancement, and noise compatibility programs (PL 100-223). According to the Department of Transportation, Office of Airport Planning and Programming guidelines, the following have been established for AIP funds:

1) Airport Planning - Funds received for airport planning may include grants for integrated airport systems addressing the current and future air transportation needs of a region as a whole. Individual airport planning needs can be funded for the current and future needs established through the airport master plan for aviation requirements, facility requirements \& compatibility with environmental and community goals.

2) Airport Development - Grants issued in this area may include funds for repair and improvement construction on airport grounds, which excludes routine maintenance. Additionally, the following may be included: land acquisition, improvement and repair of navigational aids, terminal building construction, development and repair of roadways, runways and taxiways, and site preparation. Specifically 
excluded is the construction of hangars, customer automobile parking areas, terminal art objects, decorative landscaping and building improvements not related to the safety of persons on the airport grounds.

3) Airport Capacity Enhancement and Preservation - Funds may be used for projects that significantly enhance or preserve airport capacity. Consideration for these types of funds rests on the airport's desire to improve upon these areas and the project's cost and benefit, the project's effect on overall national air transportation system capacity, and the financial commitment of the airport sponsor to preserve or enhance airport capacity. Rationale and commitment would be evidenced by the airport master plan.

4) Noise Compatibility Programs The 1982 Airport and Airway Improvement Act contained a provision to make funds available for noise compatibility planning and to carry out noise compatibility programs as authorized by the Aviation Safety and Noise Abatement Act of 1979. The specificity of this program is contained in FAR Part 150. Owners and operators of a public-use airport and/or local governments/ communities adjacent to an airport are eligible for such funds.

\section{Fund Eligibility}

To be eligible for AIP funding the airport must be a part of the National Plan of Integrate Airport Systems (NPIAS). According to Wells (2000, p 86), the criteria for inclusion in the NPIAS are minimally restrictive. The principal ones are:
- the airport has at least ten based aircraft,

- it can be at least a 30 minute drive from the nearest existing or proposed airport currently in the NPIAS system

- there is an eligible sponsor willing to undertake ownership and development of the airport.

Additionally, to qualify for AIP funding, an airport must be of the public-use variety and be characterized by one of the following criteria:

- it must have a minimum of 2,500 enplanements each year,

- it must serve the general aviation community or

- it must be designated a Reliever airport

\section{Fund Allocation}

There are more than 13,000 airports in the U.S. but only 3,304 are eligible for Federal funding under the Airport Improvement Program (AIP). Money for this program is distributed by formulas that are set forth in the law. The law divides AIP money into two broad categories: entitlement funds and discretionary funds. Entitlement funds are further divided into four sub-categories. They are:

- Primary airport entitlements;

- Cargo airport entitlements;

- State entitlements; and

- Alaskan airport entitlements.

Primary airports. If a public airport has commercial air service with at least 10,000 passenger boardings per year, it is considered a primary airport. These airports are entitled to receive AIP money each year in accordance with the following formula: 
- $\$ 7.80$ for each of the first 50,000 passengers boarded;

- $\$ 5.20$ for each of the next 50,000 passengers boarded there;

- $\$ 2.60$ for each of the next 400,000 passengers boarded; and

- 50 cents for each additional passenger boarded.

Regardless of the number of passengers boarded, the minimum entitlement is targeted to be $\$ 500,000$ per year and no primary airport is entitled to more than $\$ 22$ million per year (US House).

To receive AIP money, an airport must have a project, such as runway repair or addition, terminal extension or upgrade, or noise abatement project that is eligible for AIP funding under the law. An airport can retain the right to receive its entitlement money for 3 years. Entitlement money deferred to a later year is referred to as carryover entitlements.

Cargo entitlement. Cargo service airports are served by cargo-only (freighter) aircraft. These airports are entitled to share in a potential AIP distribution that equals $2.5 \%$ of total AIP funds. A cargo service airport shares in this available funding in the proportion to which the total weight of cargo-only aircraft operations are to the total weight of such aircraft at all other airports. No airport may receive more than $8 \%$ of the $2.5 \%$ total available AIP funds. Currently, there are 102 airports that qualify for this entitlement.

State entitlement/general aviation. The States, territories, and possessions share a potential distribution that is equal to $18.5 \%$ of total AIP funds. Each State's individual share of this distribution is based on a formula that takes into account the population and land area of the State. Money from this entitlement goes to general aviation airports (airports used by private planes) and to airports with less than 10,000 passengers per year.
General aviation airports seeking AIP money from this entitlement usually apply directly to the FAA. The FAA then decides which airports will receive appropriated funds. Nine States (Illinois, Michigan, Missouri, New Jersey, North Carolina, Pennsylvania, Tennessee, Texas, and Wisconsin) participate in the State Block Grant program. Under this program, the FAA gives the State aviation agency complete responsibility to manage its AIP allocation and the State, not the FAA, decides which general aviation airports will receive it (GAO/RCED 96-86).

Alaska entitlement. By law, Alaskan airports are entitled to receive at least the same amount of money they received in 1980. This year, they will receive about $\$ 10.5$ million. The $\$ 10.5$ million is in addition to whatever those airports receive under the above entitlements.

\section{Discretionary Funds}

The second category of funds designated for congressional "pet" projects are called Discretionary or Set Aside funds. Discretionary Funds consist of residual funds remaining after the aforementioned entitlements. They are available to any airport sponsor according to congressional mandated requirements deemed necessary for the furtherance of the aviation community. However, discretionary funds are subject to two set-asides.

Noise set-aside. The law sets aside $31 \%$ of this discretionary fund for noise projects. These could include such things as buying property for a noise buffer or soundproofing buildings.

Military Airports Program. Under the Military Airport Program, the FAA selects 12 current or former military airports to share in a set-aside that is equal to $4 \%$ of the discretionary fund. The purpose of this program is to increase overall system 
capacity by promoting joint civilian-military use of military airports or by converting former military airports to civilian use. Airports currently in the military airport program (MAP) are Myrtle, Laredo, Smyrna, Pease/Portsmouth, SanBernadino/ Norton, Austin-Bergstrom/Mueller, Homestead AFB, Millington/Memphis, Williams AFB in Arizona, Alexandria/ England AFB in Louisiana, Rickenbacker/ Columbus, and Sawyer AFB (FAA, PFC Branch).

After the entitlements and set-asides are funded, the remaining money is at the discretion of the FAA. This is often referred to as pure discretionary AIP money. Even here, however, there are restrictions. The law requires that $75 \%$ of this discretionary money be spent on airport projects that will enhance capacity, safety, or security, or reduce noise.

Minimum discretionary. Until recently, total AIP funding had been declining. At the same time, FAA has been issuing letters of intent (LOIs) to several airports. An LOI is a commitment to pay a certain amount of AIP money to an airport over a specified number of years in order to fund large costly projects. These commitments are predominantly funded from the discretionary portion of AIP. This year, $\$ 159.5$ million is committed to LOIs issued by the FAA.

The LOI is important to large, longterm airport development as the commitment of the federal government can help the airport sponsor obtain other types of funding, exclusive of the AIP monies. A cause for concern with LOI's is there can be substantial commitments made to LOI's nationally by the FAA. Such commitments would have top priority in the annual allocation of AIP funds to the detriment of other categories of AIP projects (Wells, $p$. 220).
In the past, when overall AIP program declined, much of the fund was allocated to entitlements and set-asides. This left little discretionary money and prompted concerns that the FAA would be unable to meet its LOI commitments or attend to other important projects (Kaps, 236).

As a consequence, the law now mandates the discretionary fund have at least $\$ 148$ million per year plus the amount needed to fund outstanding letters of intent issued. If the entitlement and set-aside formulas do not leave such amounts in the discretionary fund, all entitlements and setasides must be cut by a proportionate amount. In the past, this has resulted in across the board cuts in entitlements and set asides of as much as $23 \%$ to ensure the minimum discretionary fund. As a corollary to the minimum discretionary fund, the law further states that if total AIP funding is high enough such that the discretionary fund is more than the statutory minimum, any amount in that fund above the minimum would be divided $1 / 3$ to general aviation airports, $1 / 3$ to military airports, and $1 / 3$ to noise abatement programs (PL 104-264).

Nothing in the funding process is automatic. Irrespective of an airports' need and/or eligibility for funds, the operator must submit an application to the Federal Aviation Administration. Additionally, even if an airport is eligible for set-aside or discretionary money, it must submit an application for FAA review.

The AIP program is not a free ride. Just because an airport is eligible for funding does not mean that its request will be either honored or filled to the degree of total funds required. Applicants for grants must show that they are active partners in the proposed venture by having available capital of $10 \%$ to $25 \%$ of a projects' cost. This advanced requirement must be in place before the FAA begins to open its checkbook. 


\section{WHERE THE MONEY GOES}

According to the FAA, during the fiscal years between 1982 and 1996, the AIP money was spent as follows:

- $52.76 \%$ for runways; taxiways; and aprons;

- $11.2 \%$ on noise control projects;

- $7.82 \%$ for land purchases;

- $6.03 \%$ on safety and security;

- $5.2 \%$ on buildings;

- $4.78 \%$ on airport roads; and

- the remainder on miscellaneous projects such as lighting and planning.

From the standpoint of airport size, according the General Accounting Office (GAO) Annual Reports of Accomplishments Under the Airport Improvement Program, in 1996, AIP money was distributed as follows:

- $25 \%$ to the 2,764 general aviation airports;

- $24 \%$ to the 29 large hub airports;

- $17 \%$ to the 42 medium hub airports;

- $16 \%$ to the 70 small hub airports; and

- $19 \%$ to the 272 non-hub airports.

It should be noted that the reference to hubs here and elsewhere refers to the number of passengers at that airport. It has nothing to do with an airline using an airport as a connecting complex. More specifically:

- Large hubs are airports that enplane more than $1 \%$ of the total annual enplanements in the U.S. (more than 6.4 million passengers per year) and include such airports as Chicago, Atlanta, Baltimore, and Tampa;

- Medium hubs are those that enplane more than $.25 \%$ but less than $1 \%$ of annual enplanements in the U.S. (1.6 to 6.3 million passengers) and include such airports as, Cleveland, Providence, Tulsa, and Portland, Oregon.

- Small hubs enplane more than $.05 \%$ but less than $.25 \%$ of annual enplanements (324,000 to 1.6 million passengers) and include Buffalo, Norfolk, Birmingham, and Green Bay.

- Non-hubs enplane more than 10,000 passengers but less than $.05 \%$ of U.S. annual enplanements and include Akron, Moline, Topeka, and Visalia.

Table 1 indicates the amount of money provided by AIP for the select airport projects. Should the revenue stream of the airport not provide the additional capital to venture into the AIP arena, funds from other sources may become a necessity.

Since the flow of funds from AIP has been anything but stable, (See Table 2), it is important for airports to have other sources of funds for capital development. As noted in Table 2, there has been a discrepancy between Congressional Authorization of AIP and actual appropriations passed each year. There was a $\$ 700,000,000$ gap in these figures in recent years, which has been reversed in fiscal year 1998. Still, the $\$ 1.7$ billion authorized in FY 1998 does not address the tremendous airport capital improvement need identified in the NPIAS. This is especially true for Non-Passenger Facility Charge, "AIP dependent" airports. Such airports have been heavily impacted by changes in AIP funding established by Congress in the early 1990's.

\section{PASSENGER FACILITY CHARGES (PFCs)}

In 1990, Congress passed the Aviation Safety and Capacity Expansion 
Act. A portion of this Act established ability on the part of publicly owned commercial service airports to assess airport user charges on passengers utilizing their facilities. Passenger Facility Charges or PFC's, as they became known, are intended to supplement AIP by providing more money for runways, taxiways, terminals, gates and other airport improvements.

\section{PFC's, The Reliable Revenue Stream}

Those airports eligible to assess PFC's are permitted through the federal aviation administrator (FAR Part 158.5) to assess a charge of $\$ 1$ to $\$ 3$ on all domestic or international passengers enplaned at an eligible airport. If a medium or large hub airport charges a PFC, it must forego up to $50 \%$ of its AIP entitlement. The foregone entitlements go into a special small airport fund to be distributed as follows:

- $50 \%$ to non-hub airports;

- $25 \%$ to general aviation airports

- $12.5 \%$ to small hub airports; and

- $12.5 \%$ to the discretionary fund (House Subcommittee)

Recent legislation has increased the upper limit of PFC's to $\$ 4.00$ or $\$ 4.50$ with justification; however, this is still considered a special circumstance situation. Approval of a PFC above $\$ 3.00$ also has the required loss of $75 \%$ of all AIP entitlements due the requesting airport. No airport may charge a PFC of more than $\$ 3$ per passenger except through the aforementioned process; no passenger has to pay more than $\$ 12$ in PFC's per round-trip regardless of the number of airports through which the passenger connects. Finally, no airport can charge a PFC until FAA approves it (FAA PFC Branch).

These fees are collected by the airlines, travel agents and any other airline ticket issuing office at the time of travel purchase. There are 322 airports authorized to collect Passenger Facility Charges under FAR Part 158 as of March 1, 2001 and 296 approved airports are actually collecting money (House Subcommittee).

According to the FAA Passenger Facility Branch Office, $\$ 1.55$ billion in PFC funds were actually collected in CY 2000 and used as follows:

- $19 \%$ for airside projects such as runways, taxi-ways and safety related projects;

- $34 \%$ for landside projects, primarily terminal buildings;

- $30 \%$ to pay interest on bonds;

- $7 \%$ for noise abatement projects; and

- $11 \%$ for roads.

The FAA has approved virtually all airports seeking PFC revenue streams. Originally established to address definitive projects requiring additional capital, virtually all airport projects have been declared eligible for PFC funding without regard to either the need or costeffectiveness of the project (Delgado). Thus far the lone exception has been Austin/Bergstrom TX. The statutory requirement for fund usage is contained in FAR Part 158.15 that enumerates the requirements for usage and eligibility for PFC funds. In order to be eligible, a project must fall under one of the following:

1. It must preserve or enhance safety, security, or capacity of the National Air transportation system.

2. It must reduce noise or its impacts resulting from the airports' operations, or

3. It must facilitate competition amongst air carriers. 


\section{Uses of PFC Funds}

Presently, PFC revenues provide the nation's eligible airports with approximately $\$ 1.551$ billion in additional funding money. This money, because it is not tied to airline terminal usage or majority in interest clauses, strengthens an airport's ability to make spending decisions without the influence of participating airlines.

Within the confines of the three prescriptions outlined above for PFC usage, PFC funds can finance an entire project or can be used to pay debt or related expenses for bonds issued to fund an eligible project. Interestingly, PFC revenue may be used to meet the percentage requirement or airport share of projects funded under the Airport Improvement Plan (AIP).

Since 1992, PFC funding has grown to over $\$ 1.5$ billion per year for airport construction projects. As reported by the FAA's PFC Branch (2001), this funding has grown as follows since initial approval:

$\begin{array}{ll}1992 & \$ 0.085 \text { Billion } \\ 1993 & \$ 0.485 \text { Billion } \\ 1994 & \$ 0.849 \text { Billion } \\ 1995 & \$ 1.046 \text { Billion } \\ 1996 & \$ 1.113 \text { Billion } \\ 1997 & \$ 1.222 \text { Billion } \\ 1998 & \$ 1.448 \text { Billion } \\ 1999 & \$ 1.514 \text { Billion } \\ 2000 & \$ 1.551 \text { Billion }\end{array}$

However, the controversy remains regarding the appropriate use of PFC funds. Several attempts have been made to take the Trust Fund off the unified budget to prevent it from being caught in the political game of masking the national deficit.

\section{Politics of Funding}

Leaders of the airport industry have recommended that an AIP minimum funding level of $\$ 2$ billion annually be set and maintained. That level has been accomplished with the most recent funding appropriation, known as AIR 21. Though signed into law by President Clinton, there has already been information released that full authorization of the appropriation levels designated by AIR 21 are in jeopardy

There are too many examples of airports that have sought to build projects more driven by local politics, than by a desire to enhance safety or capacity. After all, of the current $\$ 29.1$ billion authorized for PFC collection, only $\$ 4.9$ billion is earmarked for safety and capacity projects such as runways, taxiways, aprons, and lighting (FAA, PFC Branch).

\section{Bonds}

After funding options such as AIP grants, PFC's, and other federal sources have been exhausted, airports and/or municipalities usually finance the costs of capital improvements through the issuance of debt. The vast majority of such debt is in the form of bonds. Bonds in the airport venue are operative and technically similar to bonds issued by a corporation. The major difference is the way bonds are backed, the taxability of such instruments, and the methods of responsibility for repayment.

Airport bonds come in a variety of types. The most common are General Airport Revenue Bonds (GARB's), General Obligation Bonds, Self-Liquidating General Obligation Bonds, and Revenue Bonds. Since these are only titles, it is important to recognize that most bonds work similarly and only the method of repayment, interest rates, maturity dates, usage purposes and responsibility for repayment may differ. 
Face value, percentage payment, yield, yield to maturity, etc. are all the same.

\section{Markets for Airport Bonds}

Airports raise literally billions of dollars annually in the debt/bond markets. This is not a new phenomenon. The first Airport Revenue Bond in the United States was issued for $\$ 2.5$ million in 1945 by the city of Miami, Florida. It was backed and was to be repaid by the proceeds of revenues from the now Miami International Airport. During the 1950s, the city of Chicago, in seeking finances for improvement of O'Hare International, took an historic step in revenue bond underwriting. In that momentous issue, the O'Hare Agreement, airlines operating into the airport agreed to back repayment. The airlines pledged that should O'Hare airport income fall short of repayment capabilities, the airlines would make up the difference by paying larger landing fees (Wells, p 223).

Airport bonds are primarily a municipal undertaking that is exempt from taxes; the buyer or owner of such bonds is not obligated to pay any taxes, either federal or state, on interest obtained through holding such debt instruments. To purchasers in high income tax brackets this tax-free instrument can provide income security without elevating them to increased tax brackets. It may permit he bondholders to obtain greater earnings than those investments paying higher returns but requiring a percentage to be paid to the Internal Revenue Service.

The tax-exempt status of municipal bond issues makes funding less expensive than other debt instruments. The rationale, because the tax-exempt nature of the bond saves investors tax money, the bonds can be issued at lower interest rates than normal debt instruments. Predictably, the vast majority of airport debt capital is raised in the tax-exempt bond market (Kaps, 245).

An interesting element to airport bonds is that since their inception, not one bond has defaulted. This, unfortunately, cannot be said for bonds issued in the corporate world.

\section{Types of Airport Bonding Issues}

General Obligation Bonds - States and municipalities issue general obligation bonds. Sometimes other subdivisions of states and municipalities have authority to issue this type of debt instrument. All bonds are agreements to pay a specific amount of money borrowed (IOU) at a certain time (maturity) with periodic (usually yearly) payments of interest. General obligation bonds are the responsibility of the citizenry of a particular locality to repay the amount borrowed including interest. The repayment to bondholders is secured by the full faith, credit, and taxing power of the issuing government agency. Thus, to have permission to undertake such a debt funding measure, the community usually must approve by vote any potential bond issues, or community indebtedness.

Although general obligation bonds may be utilized for airport construction and improvements, many compete with other local necessities for improvement and building of such programs as schools, roads, and other essential public works. This minimizes their usage as defined airport issues.

Because general obligation bonds are backed by a community guarantee to repay them at maturity, they are generally issued at lower interest rates than competing methods of securing debt. Because of this advantage, some states have set by statute the maximum amounts of general obligation debt that a municipality may incur. 


\section{Self-Liquidating General Obliga-} tion Bonds - Self-liquidating general obligation bonds are secured by the full faith and credit of the taxing power of the local citizenry, just as are general obligation bonds. The difference, however, is that cash flow from the project being financed is adequate to repay the amount of debt plus the costs to operate the project. Because of this ability to repay, the debt is not legally considered a part of the community's limitation as set for the general obligation bond. A strange anomaly occurs here, however. Since the project's performance and ultimate risk lie with the local government, who is appointed by the community, the community bears the ultimate responsibility for repayment. Due to this convoluted method of risk application, the self-liquidating general obligation bond method of funding means a higher rate of interest than the general obligation bond.

Revenue Bonds - One may imply that the terminology "revenue bond" means that they are issued to obtain revenue. In part, that is exactly what their purpose is, but that would be a misnomer for the intent of the word revenue in this case. "Revenue", in this instance, applies to the way the bond is to be repaid. Repayment of bond indebtedness is payable solely from the revenue derived from the operation of the facility, road or other project that was constructed or acquired with the bond proceeds. Funding with revenue bonds provides an opportunity to obtain airport improvements without directly burdening the taxpayer.

Some examples of revenue bonds are those issued to finance and build major highways. Generally, such highways turn to toll roads where fees are collected to repay the debt. Oftentimes when the debt is repaid the toll is extinguished and the highway becomes free to all. Similarly, revenue bonds may be issued to build a new airport terminal. The operational revenue received by the terminal acts as the catalyst for repayment.

General Airport Revenue Bonds (GARB's) - General Airport Revenue Bonds are secured solely by the operation of the airport and are not backed by any additional governmental subsidy or tax levy. In short, the citizenry of the community is not responsible for the debt service or payback of the borrowed amount. That responsibility is solely that of the airport authority.

In addition to GARB's, airports may issue a hybrid bond, or special facility bonds. Such bonds are designed to address one particular undertaking resembling an Industrial Development Bond (IDB). These may be issued to finance some specific facility, such as a new hangar or gate jet way installation, on behalf of some specific carrier. The carrier in turn directly secures the debt.

\section{Bond Ratings}

The methodology of getting bonds to market is almost the same as bonds in the corporate venue. Investment bankers also specialize in the airport bond market and their approach does not vary considerably.

The U.S. Internal Revenue Tax Code grants bonds issued to finance improvements at municipally owned airports tax exempt status. This allows bonds issued for these purposes, whether they are general obligation, revenue, general airport revenue bonds, or some other derivation to borrow at lower interest rates than corporate bonds. The precise level of the interest associated with these bonds is a direct function of the bond rating.

As with bond ratings for corporate issues, airport bonds are rated by either Standard \& Poor's or Moody's according to 
investment quality. In the airport bonds market, ratings vary between the top and medium grades issued by the rating agencies. A medium grade means that rating firms see the investment as carrying a measure of speculative risk. General obligation bonds usually draw the best ratings. Under this form of security, ratings are determined by the economic vigor of the issuing municipality. Because of this, the airport has no influence on the general obligation rating. Since Revenue bonds are directly tied to the airport, they draw ratings according to the airport's financial vitality and fiscal responsibility.

Credit analysts rank airport bonds according to a variety of factors. These include financial and operational comparables, the nature of airline rates and charges, local economic base, the airport's current financial situation, the strength of the airport management cadre, and the airport layout.

Financial and Operation Comparables In terms of airport ratio analysis, bond rating agencies will evaluate a series of different ratios that address the vitality of airport operations. Some of these may consist of:

- Debt per enplaned originating passenger

- Debt per enplaned transfer passenger

- Ratio of Originating and Departing Passenger to transfer Passengers

- Percentage of traffic generated by the primary carriers serving the airport

- Annual traffic increases

- Debt Service coverage

- Revenue per enplaned passenger

- Concessionaire revenue per enplaned passenger

- Demographics of metropolitan area
Rates and Charges to Airlines - Since these charges generate the major portion of an airport's revenue, they are strongly considered in the rating methodology. The type of rate-setting (discussed earlier) employed by the airport can give the bond rating agency a birds-eye view of the airport's control over its spending decisions. As airport revenues are the sole backing for GARB's and other revenue bonds, the nature of the airport's ability to control these revenues has considerable impact on a bond rating.

Economic Base of the Community Demand for air transportation is a function of the economic characteristics of the community served by the airport. Airports located in areas insulated from economic hardships or those in economically boom locations may receive higher bond ratings than those in depressed communities.

Current Financial Situation - All interest rates, from IOUs to bond issues, are predicated on the risk involved in the transaction. The higher the risk of having the money returned the higher the interest rate to borrow. Conversely, the greater the possibility of having the money returned the lower the charge for that money. To discern risk, you only need to look at the way and method an airport or city operates and maintains its financial house. Ratios, similar to those considered under Generally Accepted Accounting Procedures (GAAP) should provide means of determining risk.

\section{Strength of Management Team -} Traditional management values should prove beneficial to the airport seeking funding ratings. Analysts review both the managerial and administrative performance of airport operators in determining rating outcomes. Evidence of success of sound management techniques in the areas of 
planning, operating, controlling and directing the airport environment are a plus factor towards ratings.

Airport Layout - The landside and airside arrangements and setup can have a significant impact on the rating agency determination. An example of an airport layout that may engender a decision on the part of a rater to provide superior analysis would be one where all the concessionaire facilities are located in the main terminal, away from the connecting or transferring passenger. This may indicate a less than opportunistic ability on the part of the operator to achieve profit maximization.

Whatever methodology of determining bond ratings, and ultimately interest rates on bond issues, is employed, a finalized rating will eventually develop. In this setting, the ratios deemed worthy of consideration are listed as Best Grade, High Grade, Upper Medium Grade, and Medium Grade. A description of each is:

1. Best Grade: Strong capacity to pay both interest and principal with the lowest degree of risk to the bondholder

2. High Grade: Also have a strong capacity to return both principal and interest but are judged just a little less exciting than the Best Grade.

3. Upper Medium Grade: Usually are well protected in relationship to their ability to return both principal and interest but are susceptible to the potential fluctuations in Grade economy, etc.

4. Medium Grade: The protection is deemed at the time of rating; however, the presence of Grade speculative elements could impact upon the ability to pay interest or principal should economic conditions change.

Source: Moody's Bond Record, October 1996; Standard \& Poor's Rating Guide, New York, McGraw-Hill, 1995

Any grading below these would be very questionable and costly to the seeker of funds.

\section{CONCLUSIONS}

When the federal government released the airlines from its control, it changed not only the marketplace for airlines but also the entire aviation industry. One of the greatest impacts was to airports and the funding of airport growth.

Although the use of municipally issued bonds dates back to 1945, the pervasive use of bonds did not begin until after the federal deregulation of the airlines. Today, airport managers know as much about issuing the various types of bonds as do Fiscal Officers of major municipalities. In some cases, airports are forced to compete with other municipal entities for necessary bond issues to fund the expansion required to serve their community. In other cases, the airport has the necessary capitalization clout to issue their own bonds, known as GARBs. Whether issuing their own bonds or depending on the local citizenry to fund expansion, finding dependable revenue sources with which to back the bonds has become a major function in airport management.

The search for reliable funding led to the advent of PFC's. The resistance of airlines to user fees charged by airports caused the argument to end up in court. Eventually Congress passed legislation approving PFC's in particular circumstances; however, to date, only one request for PFC authorization has been denied. PFC's have allowed some airports necessary growth funding but the most common method of funding airport growth is still through 
Federal appropriation found in the Airport Improvement Program (AIP).

AIP funding has gone through several metamorphoses since its advent in 1946, but remains, to date, the single most common method of funding growth at public airports. Competition for federal dollars has become a political quagmire that has only served to elongate the process and reduce the effectiveness of the AIP. Using the revenues garnered from the various taxes and fees assessed through the Airport and Airway Trust Fund to offset general ledger shortfalls on the federal general budget has caused AIP to be constantly under funded and consistently inadequate for the aviation infrastructure growth necessary to keep pace with the airline industry the infrastructure serves.

However unreliable the federal funding process gets, the greatest impact of airline deregulation has been at the local airport level. The contractual relationship dynamic between airport and airline has set seemingly industrial allies against each other in an effort to produce revenue and profit for both. The ability of airlines to enter and leave passenger markets at will has shortened the contractual agreement times between airport and airline, thus shortening the duration of the revenue streams produced by that airline. For multi-airline served airports this is not as problematic as when a single airline is the only service at a more remote airport.

Regardless of airport size, when the funds required to pay for capacity enhancement and infrastructure maintenance are not available, safety and confidence in a highly efficient system of transportation is compromised. Although an aviation industry problem on the surface, the need for adequate, reliable airport funding has never been more important for the entire transportation industry than now. Supporting a free marketplace for airlines and general aviation through the use of constricted public monies that are doled out through political patronage and one-up-manship is at best challenging, at worst destructive. 
Table 1 Percentage of Project Monies Provided by AIP

\begin{tabular}{|l|c|c|}
\hline \multicolumn{1}{|c|}{ Project Type } & $\begin{array}{c}\text { Large } \\
\text { Primary } \\
\text { Category } \\
\text { of } \\
\text { Airports }\end{array}$ & $\begin{array}{c}\text { All Other } \\
\text { Categories of } \\
\text { Airports }\end{array}$ \\
\hline Airport Planning & $75 \%$ & $90 \%$ \\
\hline Airport Development & $75 \%$ & $90 \%$ \\
\hline Noise Compatibility Programs & $80 \%$ & $90 \%$ \\
\hline $\begin{array}{l}\text { Terminal development } \\
\text { (relievers and hub airports) }\end{array}$ & $75 \%$ & $75 \%$ \\
\hline $\begin{array}{l}\text { Terminal development } \\
\text { (commercial, non-primary } \\
\text { airports) }\end{array}$ & & $85 \%$ \\
\hline $\begin{array}{l}\text { Terminal development } \\
\text { (military airport programs) }\end{array}$ & & $90 \%$ \\
\hline
\end{tabular}

Source: Kaps, Robert W. (2000) Fiscal Aspects of Aviation Management, SIU Press, Carbondale, IL, 252)

Table 2 - AIP Funding, 1982-1998

\begin{tabular}{|c|c|c|}
\hline Fiscal Year & $\begin{array}{c}\text { Authorization } \\
\text { (millions) }\end{array}$ & $\begin{array}{c}\text { Appropriations } \\
\text { (millions) }\end{array}$ \\
\hline 1982 & $\$ 450.0$ & $\$ 450.0$ \\
\hline 1983 & 800.0 & 804.5 \\
\hline 1984 & 993.5 & 800.0 \\
\hline 1985 & 987.0 & 925.0 \\
\hline 1986 & $1,017.0$ & 885.0 \\
\hline 1987 & $1,017.0$ & $1,025.0$ \\
\hline 1988 & $1,700.0$ & $1,268.7$ \\
\hline 1989 & $1,700.0$ & $1,400.0$ \\
\hline 1990 & $1,700.0$ & $1,425.0$ \\
\hline 1991 & $1,800.0$ & $1,800.0$ \\
\hline 1992 & $1,900.0$ & $1,900.0$ \\
\hline 1993 & $2,050.0$ & $1,800.0$ \\
\hline 1994 & $2,105.5$ & $1,694.0$ \\
\hline 1995 & $2,161.0$ & $1,450.0$ \\
\hline 1996 & $2,161.0$ & $1,450.0$ \\
\hline 1997 & $2,161.0$ & $1,460.0$ \\
\hline 1998 & $1,740.0$ & $1,700.0$ \\
\hline
\end{tabular}

Source: FAA (1996), Aviation forecast 1997-2002 (Washington, D.C.: GAO); Jenkins Darryl (ed.), (1995), The handbook of airline economics (New York: McGraw Hill), 111. 


\section{REFERENCES}

Airport and Airway Improvement Act of 1982 Amendment, Pub. L. No. 100-223 SEC. 534 (1987).

Airport and Airway Improvement Act of 1982 Amendment, Pub. L. NO. 102-581 SEC. 116 (1992).

Annual Report of Accomplishments Under the Airport Improvement Program, Fiscal

Years 1982, 1983, 1993, 1994, 1995, 1996. Washington, DC: U.S. Department of

Transportation, Federal Aviation Administration.

Aviation Safety and Capacity Expansion Act of 1990, Pub. L. No. 105-508 SEC. 9114 (1990).

Delgado, Victor, "The Federal Role in Funding the National Airport System," Unpublished Master's Paper, Southern Illinois University, Carbondale, 1998.

Federal Aviation Administration Passenger Facility Charge Branch (2001) Periodic PFC Reports and Charts found online at www.faa.gov/arp/530home.htm

FAA Reauthorization Act of 1996. Pub. L. No. 104-264 SEC. 147 (1996).

Federal Aviation Administration.

Federal Aviation Regulations (FAR Part 151) FEDERAL AID TO AIRPORTS.

Washington, DC: Federal Aviation Administration

Federal Aviation Regulations (FAR Part 152) AIRPORT AID PROGRAM. Washington,

DC: Federal Aviation Administration

Federal Aviation Regulations (FAR Part 158) PASSENGER FACILITY CHARGES.

Washington, DC: Federal Aviation Administration.

Jenkins, Darryl (ed.) (1995) The Handbook of Airline Economics, New York, NY, McGraw-Hill Publishing

Kaps, Robert W. (2000) Fiscal Aspect of Aviation Management, SIU Press, Carbondale, IL

Merlis, Edward A. (1998, February). Views of the Air Transport Association concerning reauthorization of the Airport Improvement Program. Transcript of statement presented to the U.S. Senate Committee on Commerce, Science, and Transportation Hearing on reauthorization of the Airport Improvement Program, Washington, DC.

Moody's Bond Record, October 1996

Standard \& Poor's Rating Guide, New York: McGraw-Hill, 1995.

U.S. Department of Transportation, Federal Aviation Administration, Office of Airport Planning and Programming. (1993). Introduction to the Airport Improvement Program Washington.

U.S. General Accounting Office, (1998). Comparing Funding Sources with Planned Development (GAO/RCED 98-129), Washington, DC: U.S. General Accounting Office.

U.S. General Accounting Office, (1996). Airport Improvement Program: State Block Grant Program (GAO/T-RCED-96-86). Washington, DC: U.S. General Accounting Office.

U.S. General Accounting Office, (1994). Airport Improvement Program, Program Funding by State Relative to Enplanements for Selected Years (GAO/RCED-94-7FS) Washington, DC: U.S. General Accounting Office. 
US House of Representatives, Aviation Subcommittee (2001, February) Current AIP and Trust Fund Summaries; online: www.house.gov/transportation/press/aipbgr.htm

Wells, Alexander T. (2000). Airport Planning and Management, 4th. Ed., New York, NY, McGraw-Hill

Whitlock, E. M. (1992, January). Funding Airport Facilities. Transportation Quarterly, 46, 99-114.

Zorn, C. K. (1990, Spring). The Airport and Airway Trust Fund: A Continuing Controversy. Public Budgeting \& Finance, 10, 13-25. 